ommendations and the rationale for the decisions.

"The details still have to be worked out," she says. "Of course these won't be cookie cutter decisions, but there will be a public face explaining what has been recommended."

It is expected that reviews of oncology drugs will be completed within four to five months, which O'Reilly says is an acceptable time frame.

The new review process is still in development, and currently the interim steering committee is working on staff recruitment and a Memorandum of Understanding between its partners, including the Canadian Agency for
Drugs and Technology in Health and the Canadian Partnership Against Cancer.

The final steering committee will be composed of six senior-level representatives from the provinces and four senior-level cancer agency representatives, with representatives from the Canadian Agency for Drugs and Technology in Health and the Canadian Partnership Against Cancer acting as observers.

Development of the national review was set in motion in 2006 by Canada's provincial and territorial premiers. In 2007, an interim Joint Oncology Drug Review initiative was launched, in which Ontario's oncol- ogy drug review process was studied as a model for the national review process, with other provinces participating as observers.

In Canada, $45 \%$ of men and $39 \%$ of women develop cancer in their lifetime, and about one in four die of the disease. A presentation made by the review's cochairs in April indicates that expenditures on cancer drugs and biologics now occupy $30 \%$ of provincial cancer budgets and the annual growth rate of oncology drug sales is roughly double that of the overall pharmaceutical market. - Lauren Vogel, Ottawa, Ont.

DOI:10.1503/cmaj.109-3262

\title{
National standards for electronic health records remain remote
}

Previously published at www.cmaj.ca

$\mathrm{T}$ en years after the federal government agreed to build a national "infostructure" for electronic health records (EHRs), confusion and disarray appear to be the only form of national standards in operation within health information record-keeping circles.

Several physicians and academic experts say the political will to implement national standards appears non-existent. EHR vendors are fuming. Health Canada stepped into the fray by introducing new certification and licensing requirements, some of which are fuzzy. Canada Health Infoway, meanwhile, has thrown its hands into the air and says it has no authority to compel provinces to comply with national standards.

And federal Auditor General Sheila Fraser again waded into the murky EHR waters on Apr.20 and updated a November 2009 report that concluded Infoway has had little success in removing interprovincial barriers and, therefore, little "assurance that EHR systems will be correctly implemented."

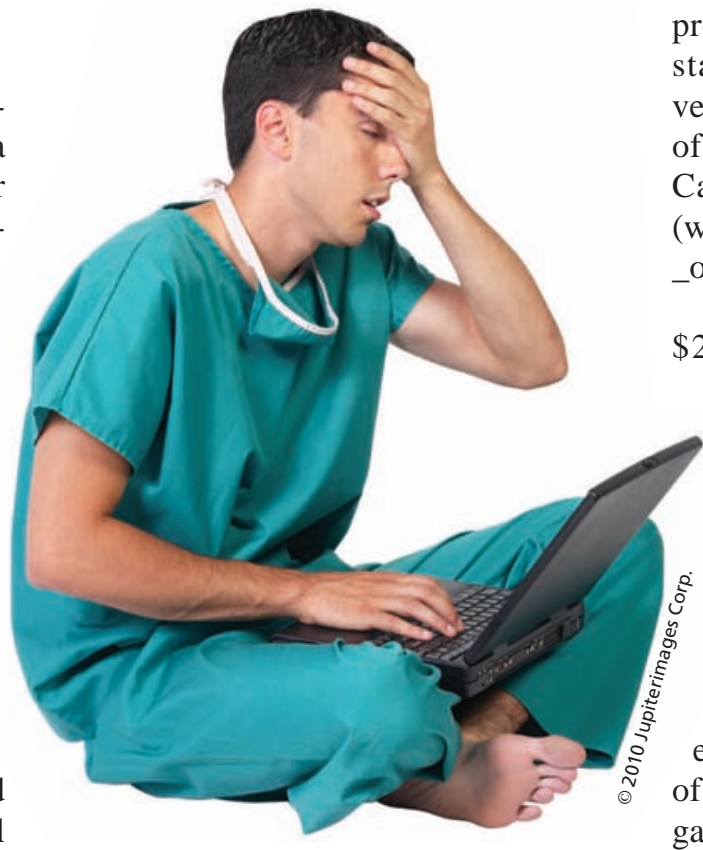

provinces continue to create separate standards that oblige national EHR vendors to conform to a dizzying array of local requirements instead of panCanadian standards, Fraser reported (www.oag-bvg.gc.ca/internet/docs/parl _oag_200911_04_e.pdf).

The incongruities compromise the $\$ 2.1$-billion federal investment in

Infoway and present "risks to high-quality health care, patient safety, and the privacy of patient information," Fraser added.

Some observers say the problems start at the top.

"We don't really have any federal governance," says Dr. Alexander Jadad, Canada Research Chair in ehealth innovation at the University of Toronto in Ontario, Princess Margaret Hospital physician and founding director of the Centre for Global eHealth Innovation.

Jadad, who recently chaired a panIssues relevant to clinicians have not been addressed in the development of standards for electronic health records, some experts say.

Instead of a single national marketplace for electronic health information products such as software for managing patient medical records, many
European meeting at which 27 other governments agreed to adopt unified standards, says successful integration of interjurisdictional EHR systems depends on high-level political leadership. Coherent national standards are "a clear priority and governments 
have to figure out how to make people comply with these standards," he says. "That is the role of the national government."

Others are as disturbed by Health Canada's August 2009 decision to
Frontline health care providers appear equally disgruntled.

Canada Health Infoway has not focused on issues relevant to clinicians, says Dr. Alan Brookstone, a family physician in Vancouver, British

\section{"In order to establish good national policy we require strong leadership with respect to EMR [electronic medical record] adoption and use, something that at this time does not exist." -Dr. Alan Brookstone, family physician}

commence policing data management products. In an unexpected decree that was released without advance consultation or subsequent opportunity for comment from industry or health practitioners, Health Canada announced that it would obligate all manufacturers of electronic products that manage patient data to comply with certification procedures. In addition, EHR products would have to meet undefined licensing requirements.

Nine months later, Health Canada has yet to respond to requests from the Information Technology Association of Canada for clarification on what the decrees mean for vendors, provincial health ministries, regional health networks, hospitals, community clinics and physicians.

The announcement came "as an absolute total shock" to EHR vendors, says Brendan Seaton, the head of the Informational Technology Association of Canada's health division. "For more than 30 years, we never heard about the idea of imposing these kinds of regulations."

Seaton adds that the industry doesn't take issue with the imposition of federal safety standards but feels ambushed by Health Canada. Combined with the turmoil over performance standards and "what you have is a poor battered industry getting absolutely hammered," he says. "They haven't consulted with us at all. If they had, a lot of grief could have been avoided."
Columbia, who just completed a twoyear term as chair of Infoway's clinical subcommittee on standards.

"It's like they are trying to build a point-of-sale system in which they have no ability to issue sales receipts," says Brookstone, who has launched a company to help physicians navigate the EHR minefield. "At this point, a big part of what the federal officials are doing is protecting their butts. In order to establish good national policy we require strong leadership with respect to EMR [electronic medical record] adoption and use, something that at this time does not exist."

There's no question that national standards would be of value, says Kahled El Eman, Canada Research Chair in Electronic Health Information at the University of Ottawa in Ontario. It would allow vendors to "spend fewer resources getting certified repeatedly and focus on improving their products. They should be certified once and that should be enough for the whole country."

But El Eman notes that balkanized jurisdiction over health care in Canada creates a legal and political mess that federal health information officials are not empowered to disentangle.

Dennis Giokas, chief information officer for Canada Health Infoway, says the nonprofit organization cannot compel provincial compliance with national standards. The organization has completed a catalogue of national standards "and our focus is now on implementation," he says. "There are differences among jurisdictions. We're trying to get consistency. The devil's always in the details."

The slow pace of adoption "is often a function of how quickly the provinces move," Giokas adds, and every province "is on its own path."

Health Canada spokesman Stephane Shank says the department decided to begin policing health information technologies because many products were starting to be used for "diagnositic decisions and patient treatment options," not just patient records.

"Uncertainty regarding these products' legal status" has led to "many unlicensed medical devices being available on the Canadian market," he says, adding that the devices are still being allowed on the market, while their manufacturers seek licences.

Shank adds that Health Canada will soon offer an 18-month transitional "amnesty period" to give manufacturers additional time to comply with the new requirements. - Paul Christopher Webster, Toronto, Ont.

DOI:10.1503/cmaj.109-3239

Sixth of a series on electronic health records.

Part I: Canada's electronic health records initiative stalled by federal funding freeze (CMAJ 2010:

DOI:10.1503/cmaj.109-3183)

Part II: Ontario's plan for electronic health records is at risk, official says (CMAJ 2010: DOI:10.1503/cmaj .109-3193)

Part III: Electronic health records a "strong priority" for US government (CMAJ 2010: DOI:10.1503/cmaj .109-3218)

Part IV: The pocketbook impact of electronic health records: PRO (CMAJ 2010: DOI:10.1503/cmaj.109-3225)

Part V: The pocketbook impact of electronic health records:CON (CMAJ 2010: DOI:10.1503/cmaj.109-3226) 